\title{
Structural-Property Relationship in Activated Carbon Synthesized from Rice Straw for Electronic Application
}

\author{
Mahmoud Abdel Daiem ${ }^{1,6}$, Abdullah A. Alotaibi ${ }^{2}$, Eid M. Alosime ${ }^{3}$, \\ Boubaker Zaidi ${ }^{4,5 *}$, Noha Said ${ }^{6}$
}

${ }^{1}$ Civil Engineering Department, College of Engineering, Shaqra University, Dawadmi, Ar Riyadh, Saudi Arabia ${ }^{2}$ Department of Chemistry, College of Sciences and Humanities, Shaqra University, Ad-Dawadmi, Saudi Arabia ${ }^{3}$ National Center for Irradiation Technology, King Abdulaziz City for Science and Technology, Riyadh, Saudi Arabia

${ }^{4}$ Department of Physics, College of Sciences and Humanities, Shaqra University, Ad-Dawadmi, Saudi Arabia ${ }^{5}$ Université de Monastir, Laboratoire Physico-chimie des Matériaux, Faculté des Sciences de Monastir, Département de Physique, Monastir, Tunisia

${ }^{6}$ Environmental Engineering Department, Faculty of Engineering, Zagazig University, Zagazig, Egypt

Received: 30 November 2019

Accepted: 3 February 2020

\begin{abstract}
Activated carbons have been prepared from rice straw by considering the material forms of rice straw, the chemical activation agent and the preparation method. The study seeks optimal conditions for giving better mico- and nano- properties, and to support the corresponding molecular structure. All the obtained results are referred to those of a commercial sample. Fourier transform infrared absorption, $\mathrm{X}$-ray photoelectron spectroscopy, and dispersive X-ray spectroscopy are combined to determine functional groups. Moreover, a quantum chemical calculation has been done using density functional theory to argue the proposed molecular structure. Principally, the vibrational properties are compared to experimental results, and the corresponding electronic structure is calculated. Thermal stability and eventual reactions are evidenced by both differential and gravimetric thermal analysis. The surface topography of the resulting activated carbon is checked by scanning electron microscope and correlated with their chemical and textual characteristics carried out from Brunauer, Emmett and Teller analysis. Results illustrate that the resulting product is a mixture of carbon graphic structure and acidic/basic entities and exhibit a global acidic $\mathrm{pH}$. The use of $\mathrm{KOH}$ as oxidant agent and the ground raw material form leads to obtain good properties such as higher surface area and higher porosity. Based on the size compatibility making it possible to introduce low-radius single-walled carbon nanotubes, the electronic structures of the prepared activated carbon and that of chiral $(5,5)$ SWCNTs and their corresponding
\end{abstract}

*e-mail: boubaker@su.edu.sa 
frontier molecular orbitals have been carried out at the DFT/6-31-G(d) level. These calculations are carried out to evidence the charge transfer between both components in the bulk hetero-nano-junctions as interpenetrating network.

Keywords: activated carbon, waste rice straw, specific surface, molecular structure, charge transfer

\section{Introduction}

Agricultural wastes are produced with a huge amount in Egypt [1]. Rice straw represents the most unutilized crop residue in Egypt, accounting for 3.61 million tons per year [2-5]. It causes environmental pollution and contributes to black cloud formation when it is burned in the open atmosphere [6]. Therefore, its exploitation in the industrial sector will certainly contribute to improving the ecological environment as well as participating in technological development [7]. In this context, one of the most promising methods is its transformation to carbon materials $[8,9]$. The activated carbons (ACs) produced from agricultural residue can be used as adsorbents/bioadsorbants in adsorption and photocatalytic degradation to reduce the environmental pollution in aqueous and gaseous solutions [10-17]. These porous carbon structures have a special interest due to their specific surface areas and higher aptitude to adsorb aqueous and gaseous pollutants [1]. The synthesis process of ACs from rice straw is largely studied in the literature, and the resulting product has been already commercialized by using different precursors [18-20]. It has been demonstrated that some parameters included in the preparation process (activation and carbonization processes, activation agent, temperature, time of activation, and the sample post treatment) can affect $\mathrm{AC}$ properties such as textural and chemical characteristics. Different activation agents are used to prepare ACs from rice straw such as $\mathrm{HNO}_{3}, \mathrm{H}_{2} \mathrm{O}_{2}, \mathrm{KMnO}_{4}, \mathrm{ZnCl}_{2}$ and $\mathrm{H}_{3} \mathrm{PO}_{4}$ in order to improve surface area, which represents the major parameter, typically ranging from 63 to $771 \mathrm{~m}^{2} / \mathrm{g}[7-11,18-20]$. Whereas the integration of ACs on some technology sectors is relatively developed, principally on pollutant adsorption, their use in the electronic field is still limited.

When compared with the existing polymeric materials, the porous carbon materials provide advanced characteristics. Especially their porosity at the nanometer scale and their specific surface classify them as a good candidate to be functionalized with nanomaterials serving as active layers to redefine the sophisticated flexible electronics [21]. Lowerradius carbon nanotubes, namely single-walled carbon nanotubes (SWCNTs), exhibit good compatibility with pore size and can consequently establish an interpenetrating network. The resulting bulk heteronano-junctions can drive charge transfer, which is a major factor for powering conversion and also plays the role of electron-hole separation. Otherwise, single SWCNTs exhibit a good factor form and good transport properties due to the high electrons and hole mobilities
[22]. Therefore, the use of these lower-cost materials as active layers seems to be a promising way to develop new preferment devices for compact electronics [23].

From this background, the main objectives of this work were preparation of different ACs by using design of experiment (DOE) by studying three variables such as material state (M), chemical activation agent (CA), and preparation method (P). Our aim is to evidence the optimum conditions, allowing them to reach higher surface area and good micropore properties. In order to make a difference between the prepared ACs, a first selection based on chemical and textual characteristics of all combinations of the used variables is evidenced. All the obtained results are referred to those obtained from a commercial activated carbon cloth (CC). On the other hand, some structural technics are used to support both molecular structure and micro- and nano properties for the selected prepared ACs and CCs. These technics include Fourier transform infrared absorption (FTIR), X-ray photoelectron spectroscopy (XPS), energydispersive X-ray (EDX) spectroscopy, differential and gravimetric analysis (DTA-TGA) and scanning electron microscope (SEM). Moreover, theoretical calculations have been done using density functional theory (DFT). Otherwise, and based on the good compatibility either geometrically or electronically with SWCNTs, both electronic structures and frontier molecular orbitals are also calculated in order to evidence the charge transfer process between both components.

\section{Materials and Methods}

\section{Chemical Reagents}

All chemical reagents used in this study were zinc chloride $\left(\mathrm{ZnCl}_{2}\right)$, potassium hydroxide $(\mathrm{KOH})$, hydrochloric acid $(\mathrm{HCl})$, and hydrofluoric acid (HF). All high-purity analytical-grade reagents were supplied by Sigma-Aldrich. All the ultrapure water used were obtained from Milli-Q equipment Millipore.

\section{Rice Straw Characterization}

The rice straw used in this study was obtained from Andalusia, Spain. Moisture content, ash content, volatile matter, elemental analysis and lignin, glucose, cellulose and hemicellulose content of straw samples as well as ash composition were determined according to methods described below. All analyses were carried out in triplicate and the average values were taken. 
Moisture content of straw samples was determined by drying at $378^{\circ}+2 \mathrm{~K}$ to a constant weight, according to UNE-EN 14774-2 [24]. Ash content was determined by igniting the straw samples in a muffle furnace at $923^{\circ} \mathrm{K}$ according to UNE-EN 14775 [25], and volatile matters were determined at $1173^{\circ} \mathrm{K}$ according to UNEEN 15148 [26]. Elemental analysis for the rice straw and the straw ash samples was performed according to UNE-EN 15104 [27] and UNE-EN 15290 [28], respectively. The lignin content was determined by acid hydrolysis according to Sluiter et al. [29], and was measured by UV-spectrophometry $\left(\mathcal{E}_{205}=110 \mathrm{~L} / \mathrm{g} \mathrm{cm}\right)$. Glucose was quantified with the glucose-TR kit (Spinreact) and the reducing sugars were determined with the Somogyi-Nelson method [30]. Finally, the cellulose content was calculated from the glucose, and the difference between total reducing sugar and glucose corresponded to the sugars from hemicellulose, using an anhydro correction of 0.90 and 0.89 for calculating cellulose and hemicellulose, respectively.

\section{Preparing and Characterizing Pellets}

The straw was milled to a size less than $4 \mathrm{~mm}$ using a VIKING electric garden shredder with chipping unit and $2500 \mathrm{~W}$ power (GE150). A well-proven KAHL 14-175 flat die pelleting press with a nominal power of $3 \mathrm{~kW}$ was used to manufacture pellets, according to Said et al. [31]. After the temperature of the produced pellets was reduced by the ambient air, the pellets were packaged in plastic bags and stored at ambient temperature far from heat and moisture for subsequent characterization and analysis in order to determine moisture content, hardness, durability, particle and bulk densities as described previously [31]. All of these analyses were run in triplicate for randomly chosen pellet samples in each experiment, and the average values of the measurements were taken.

Similarly, to the case of rice straw, moisture content of pellets was measured by drying samples in an air oven at $378^{\circ} \pm 2 \mathrm{~K}$ to a constant weight, according to UNE-EN 14774-2 [24]. The length and diameter of pellets were measured using a digital vernier caliper CLD-150, according to UNE-EN 16127 [32]. The particle density of pellets was determined according to UNE-EN 15150 [33] by weighing the individual pellet and calculating its volume based on the pellet dimensions. To calculate the bulk density, the volume and the weight of the pellet samples were measured according to UNE-EN 15103 [34]. Hardness was measured using a KAHL tester working between 0 and $100 \mathrm{~kg}$, and finally the durability was determined according to UNE-EN 15210-1 [35] using a New Holmen tester.

\section{Preparing and Characterizing Activated Carbons}

ACs were prepared from two material forms of rice straw (grinded raw material, $\mathrm{R}$, and pellet, $\mathrm{P}$ ) using two chemical activation agents $\left(\mathrm{KOH}: \mathrm{K}\right.$, and $\left.\mathrm{ZnCl}_{2}: \mathrm{Z}\right)$ and two preparation methods (origin: $\mathrm{O}$, and carbonization: $\mathrm{C})$. In the $\mathrm{O}$ preparation method, the rice straw was mixed with the activation agent with impregnation ratio 1:1 by weight for two days at $333^{\circ} \mathrm{K}$, and the samples were pyrolyzed under $\mathrm{N} 2$ (flowrate $=300 \mathrm{~cm}^{3} / \mathrm{min}$ ) at $573^{\circ} \mathrm{K}$ for $2 \mathrm{~h}$ and then at $1173^{\circ} \mathrm{K}$ for $1 \mathrm{~h}$ at a heating rate $10^{\circ} \mathrm{C} / \mathrm{min}$. The $\mathrm{C}$ method has the same previous procedure expect starting with a pre-treatment carbonization process where pyrolyzes the $\mathrm{R}$ or $\mathrm{P}$ samples under $\mathrm{N} 2$ (flowrate $=300 \mathrm{~cm}^{3} / \mathrm{min}$ ) at $623^{\circ} \mathrm{K}$ for $2 \mathrm{~h}$ at a heating rate of $10^{\circ} \mathrm{K}{ }^{\circ} \mathrm{C} / \mathrm{min}$ then followed the previous process.

To remove the $\mathrm{KOH}$ from prepared ACs, the samples washed with $0.10 \mathrm{M} \mathrm{HCl}$ and then with distilled water until chloride ions were no longer detected in the washing water by using a silver nitrate solution. Moreover, to reduce the percentage of silica in carbon samples, the carbons were immersed in HF for 3 days at $323^{\circ} \mathrm{K}$ with continuous stirring, then we filtered the sample and finally washed with distilled water until solution $\mathrm{pH}$ was stable. The washed samples were then dried at $383^{\circ} \mathrm{K}$ for $24 \mathrm{~h}$.

Multivariate analysis has become the most important process for obtaining valuable and statistically significant models for preparation of materials by performing a minimum set of well-chosen experiments. The importance of each variable and their interactions will be obtained by using the design of experiment (DOE). Thus, a two-level full factorial design was applied to investigate the effect of material form ( $\mathrm{R}$ or $\mathrm{P})$, chemical activation agents $(\mathrm{K}$ or $\mathrm{Z})$ and preparation methods ( $\mathrm{O}$ or $\mathrm{C}$ ), with a total of 8 experiments run using Statistica software version 8 (Table 1). Consequently, the equation of the polynomial regression design and the 2-way interaction effects of 3 predictor variables, material form $(\mathrm{M})$, chemical activation agents (CA), and preparation methods (P) is fitted by the following equation:

$\mathrm{Z}=\beta_{0}+\beta_{1} \mathrm{M}+\beta_{2} \mathrm{CA}+\beta_{3} \mathrm{P}+\beta_{4} \mathrm{M} \times \mathrm{CA}+\beta_{5} \mathrm{M} \times \mathrm{P}+\beta_{6} \mathrm{CA} \times \mathrm{P}$

Table 1. Full factorial design of experiments.

\begin{tabular}{|c|c|c|c|}
\hline Exp. No. & $\mathrm{M}$ & $\mathrm{CA}$ & $\mathrm{P}$ \\
\hline 1 & $\mathrm{R}$ & $\mathrm{K}$ & $\mathrm{O}$ \\
\hline 2 & $\mathrm{P}$ & $\mathrm{K}$ & $\mathrm{O}$ \\
\hline 3 & $\mathrm{R}$ & $\mathrm{Z}$ & $\mathrm{O}$ \\
\hline 4 & $\mathrm{P}$ & $\mathrm{Z}$ & $\mathrm{O}$ \\
\hline 5 & $\mathrm{R}$ & $\mathrm{K}$ & $\mathrm{C}$ \\
\hline 6 & $\mathrm{P}$ & $\mathrm{K}$ & $\mathrm{C}$ \\
\hline 7 & $\mathrm{R}$ & $\mathrm{Z}$ & $\mathrm{C}$ \\
\hline 8 & $\mathrm{P}$ & $\mathrm{Z}$ & $\mathrm{C}$ \\
\hline
\end{tabular}

Where, $\mathrm{M}$ is the material of rice straw, $\mathrm{CA}$ is the chemical agent, and $\mathrm{P}$ is the processes 
Table 2. Rice straw analysis data and major elements of straw ash.

\begin{tabular}{|c|c|c|}
\hline Analysis $^{1}$ & Element & Value (\%) \\
\hline \multirow{3}{*}{$\begin{array}{l}\text { Component } \\
\text { analysis }\end{array}$} & Lignin & 20.69 \\
\hline & Cellulose & 33.65 \\
\hline & Hemicellulose & 26.68 \\
\hline \multirow{3}{*}{$\begin{array}{l}\text { Proximate } \\
\text { analysis }\end{array}$} & Moisture & 8.39 \\
\hline & Ash & 10.90 \\
\hline & Volatiles & 89.80 \\
\hline \multirow{3}{*}{$\begin{array}{l}\text { Ultimate } \\
\text { analysis }\end{array}$} & $\mathrm{C}$ & 41.24 \\
\hline & $\mathrm{H}$ & 6.99 \\
\hline & $\mathrm{N}$ & 0.63 \\
\hline \multirow{7}{*}{$\begin{array}{l}\text { Elemental } \\
\text { composition } \\
\text { of ash }\end{array}$} & $\mathrm{SiO}_{2}$ & 49.99 \\
\hline & $\mathrm{K}_{2} \mathrm{O}$ & 18.14 \\
\hline & $\mathrm{CaO}$ & 6.44 \\
\hline & $\mathrm{MgO}$ & 3.37 \\
\hline & $\mathrm{Na}_{2} \mathrm{O}$ & 2.72 \\
\hline & $\mathrm{P}_{2} \mathrm{O}_{5}$ & 1.05 \\
\hline & $\mathrm{SO}_{3}$ & 2.05 \\
\hline
\end{tabular}

${ }^{1}$ Based on dry weight except moisture content

..where $\mathrm{Z}$ represents characteristics of carbon as response of variables effect, and $\beta \mathrm{i}(\mathrm{i}=[0,6])$ are regression coefficients that are useful in generating a relationship between variables and property response.

The commercial carbon CC was also studied; it was washed with ultrapure water, dried in an oven at $110^{\circ} \mathrm{C}$, and then all carbon samples were stored in a desiccator. The ACs and CC were chemically and texturally characterized. The methods and techniques used in characterization are detailed by Rivera et al. (2003, 2004) [36, 37].

\section{Chemical and Surface Characteristics of $\mathrm{ACs}$ and $\mathrm{CC}$}

FTIR measurements are taken from $\mathrm{KBr}$ pellets mixed with the organic compound, as is the case in our previous study [38], using PerkinElmer FT-IR spectrometers, USA from a wavelength of 4000 to $650 \mathrm{~cm}^{-1}$, with a number of scans equal to 32 and a resolution of $2 \mathrm{~cm}^{-1}$. To ensure the molecular structure of the obtained ACs, FTIR experimental data are supported by those obtained theoretically from quantum calculations based on density functional theory (DFT). This theoretical method is the most appropriate tool to describe the organic materials properties [39, 40]. The modeling structure has been fully optimized using the most popular Becke's three-parameter hybrid functional, B3 [41], with the basis set 6-31-G (d). Calculations applied to the modeling structure are done with nonlocal correlation of Lee-Yang-Parr, LYP, abbreviated as B3LYP method [42] without constraint, which is often used in in our previous calculations [43].

The surface morphology of the ACs were observed by SEM (JEOL JSM-IT300, Japan) operating with $10 \mathrm{KV}$ voltage, making it possible to obtain electron beams of a very large smoothness, reaching a space resolution of a few tens of nanometers [44]. In addition, the SEM was equipped with an energy-dispersive X-ray spectroscopy module (EDS, Oxford, UK) for surface element analysis.

XPS spectra were recorded on a JEOL: JPS-9200 with monochromatic $\mathrm{Al} \mathrm{Ka}(1486.6 \mathrm{eV})$ radiation. The electron-binding energies (EB) were obtained without charge compensation.

DTA and TGA analysis and measurements are delivered using thermo-balance Pyris 1 TGA, Perkin Elmer, USA. The sample weight of approximately $10 \mathrm{mg}$ was placed in an alumina $70 \mu \mathrm{l}$ crucible. The temperature was held isothermally at room temperature in order to give water sufficient time to evaporate prior to heating to $1023^{\circ} \mathrm{K}$ at a constant rate of $10^{\circ} \mathrm{K} / \mathrm{min}$.

\section{Results and Discussion}

As shown in Table 2, cellulose represented the largest component of lignocellulose materials of rice straw, followed by hemicellulose and lignin with values of $33.65 \%, 26.68 \%$ and $20.69 \%$, respectively. Moreover, the high volatiles content means that this residue has a high content of carbon material, which is very useful for converting it to ACs. This hypothesis is confirmed by the carbon content, which represents the highest percentage reaching $41.24 \%$. Furthermore, the high ash content $(10.90 \%)$ is attributed to the high content of silica, and potassium oxide, which was detected in element composition of ash at $49.99 \%$ and $18.14 \%$, respectively. Table 3 shows the fabrication conditions of the used pellets and its characteristics.

The chemical and textual characteristics of the prepared ACs are summarized in Table 4. Surface area determined from $\mathrm{N}_{2}$ adsorption isotherms at $77 \mathrm{~K}$ are closely in good agreement with the volumes

Table 3. Pellet characterization.

\begin{tabular}{|c|c|c|c|c|c|c|}
\hline $\begin{array}{c}\text { Moisture content } \\
(\%)\end{array}$ & $\begin{array}{c}\text { Length } \\
(\mathrm{mm})\end{array}$ & $\begin{array}{c}\text { Diameter } \\
(\mathrm{mm})\end{array}$ & $\begin{array}{c}\text { Hardness } \\
(\mathrm{kg})\end{array}$ & $\begin{array}{c}\text { Durability } \\
(\%)\end{array}$ & $\begin{array}{c}\text { Particle density } \\
\left(\mathrm{kg} / \mathrm{m}^{3}\right)\end{array}$ & $\begin{array}{c}\text { Bulk density } \\
\left(\mathrm{kg} / \mathrm{m}^{3}\right)\end{array}$ \\
\hline 14.80 & 2.49 & 8.09 & 21.00 & 99.31 & 1260 & 740 \\
\hline
\end{tabular}


Table 4. Chemical and textual characteristics of prepared activated carbon according to design of experiment.

\begin{tabular}{|c|c|c|c|c|c|c|c|c|c|c|c|c|}
\hline $\begin{array}{l}\text { Exp. } \\
\text { No. }\end{array}$ & M & $\mathrm{CA}$ & $\mathrm{P}$ & $\begin{array}{c}\mathrm{S}_{\mathrm{N}^{a}}{ }^{\mathrm{a}} \\
\left(\mathrm{m}^{2} \mathrm{~g}\right)\end{array}$ & $\begin{array}{c}\mathrm{W}_{\mathrm{o}}\left(\mathrm{N}_{2}\right)^{\mathrm{b})} \\
\left(\mathrm{cm}^{3} / \mathrm{g}\right)\end{array}$ & $\begin{array}{c}\mathrm{W}_{\mathrm{o}}\left(\mathrm{CO}_{2}\right)^{\mathrm{c})} \\
\left(\mathrm{cm}^{3} / \mathrm{g}\right)\end{array}$ & $\begin{array}{c}\mathrm{L}_{\mathrm{o}}\left(\mathrm{N}_{2}\right)^{\mathrm{d})} \\
(\mathrm{nm})\end{array}$ & $\begin{array}{c}\mathrm{L}_{\mathrm{o}}\left(\mathrm{CO}_{2}\right)^{\mathrm{e})} \\
(\mathrm{nm})\end{array}$ & $\begin{array}{c}\text { Total acidic } \\
\text { groups }{ }^{\mathrm{f}} \\
(\mathrm{meq} / \mathrm{g})\end{array}$ & $\begin{array}{c}\text { Total basic } \\
\text { Groups g) } \\
\text { (meq/g) }\end{array}$ & $\mathrm{pH}_{\mathrm{pzc}}{ }^{\mathrm{h}}$ & $\begin{array}{c}\left.\text { Ashes }{ }^{j}\right) \\
(\%)\end{array}$ \\
\hline 1 & $\mathrm{R}$ & K & $\mathrm{O}$ & 866 & 0.35 & 0.40 & 1.18 & 0.83 & 8.15 & 2.12 & 5.6 & 0.29 \\
\hline 2 & $\mathrm{P}$ & K & $\mathrm{O}$ & 1297 & 0.52 & 0.50 & 1.21 & 0.74 & 8.90 & 3.84 & 4.9 & 10.22 \\
\hline 3 & $\mathrm{R}$ & Z & $\mathrm{O}$ & 699 & 0.31 & 0.21 & 0.70 & 0.54 & 11.00 & 8.00 & 5.5 & 1.20 \\
\hline 4 & $\mathrm{P}$ & Z & $\mathrm{O}$ & 650 & 0.25 & 0.20 & 0.71 & 0.59 & 10.12 & 4.12 & 5.1 & 3.12 \\
\hline 5 & $\mathrm{R}$ & K & $\mathrm{C}$ & 1000 & 0.40 & 0.43 & 0.74 & 0.70 & 11.87 & 5.41 & 5.1 & 0.10 \\
\hline 6 & $\mathrm{P}$ & $\mathrm{K}$ & $\mathrm{C}$ & 690 & 0.21 & 0.16 & 0.70 & 0.60 & 7.02 & 0.01 & 3.1 & 1.17 \\
\hline 7 & $\mathrm{R}$ & Z & $\mathrm{C}$ & 1007 & 0.40 & 0.26 & 1.23 & 0.66 & 11.22 & 8.10 & 6.0 & 0.10 \\
\hline 8 & $\mathrm{P}$ & Z & $\mathrm{C}$ & 712 & 0.28 & 0.23 & 1.25 & 0.64 & 11.11 & 3.54 & 5.2 & 0.25 \\
\hline
\end{tabular}

a) Surface area determined from $\mathrm{N}_{2}$ adsorption isotherms at $77 \mathrm{~K}$,

b, c) Volumes of micropores determined by $\mathrm{N}_{2}$ and $\mathrm{CO}_{2}$ adsorption, respectively,

d, e) Mean widths of micropores determined with the Dubinin equation,

f) Concentration of acidic groups determined by titration with $\mathrm{NaOH}(0.1 \mathrm{~N})$,

g) Concentration of basic groups determined by titration with $\mathrm{HCl}(0.1 \mathrm{~N})$,

h) $\mathrm{pH}$ of the point of zero charge,

j) Ash content at $550^{\circ} \mathrm{C}$.

of micro-pores determined by $\mathrm{N}_{2}$ and $\mathrm{CO}_{2}$ adsorption. The obtained surfaces vary from $650 \mathrm{~m}^{2} / \mathrm{g}$ to $1297 \mathrm{~m}^{2} / \mathrm{g}$, depending on the factorial design of experiments. It is noteworthy that these specific surfaces are the consequence of a relatively higher micro-pore volumes (ranging from $0.20 \mathrm{~cm}^{3} / \mathrm{g}$ to $0.52 \mathrm{~cm}^{3} / \mathrm{g}$ ). The corresponding mean widths of microspores determined with the Dubinin equation are in the range $(0.54 \mathrm{~nm}$ to $1.25 \mathrm{~nm})$. Moreover, all the obtained ACs have an acidic $\mathrm{pH}$ where both acidic and basic entities are present.

Table 5 shows the regression coefficients of the variables for surface area, volume and mean widths of micropores. It is clearly seen that the surface area and mean width of micropores have a high goodness with fitted data, which give an impression about the importance of both of them. The results show also that the use of $\mathrm{KOH}$ and raw material is the most appropriate way to give the higher specific surface area as is the case with some other previously published works $[45,46]$. Fig. 1 shows the variation of surface area of prepared ACs at different chemical agents and material of rice straw as a function of preparation methods. The surface area is the most important parameter among different chemical and textural parameters used for environmental and/or super-capacitor applications [10, 11]. Moreover, by referring to the commercial cloth ACs (CC) (Table 6) and when considering only those having surface area higher than $700 \mathrm{~m}^{2} / \mathrm{g}$, only samples numbered 1, 2, 5, 7 and 8 will be selected.

Table 5. Regression coefficients of the variables for surface area, volume of micropores and mean widths of micropores.

\begin{tabular}{|c|c|c|c|c|c|c|c|c|c|}
\hline & \multicolumn{3}{|c|}{ Surface area } & \multicolumn{3}{|c|}{ Volume of micropores } & \multicolumn{3}{|c|}{ Mean widths of micropores } \\
\hline & $\beta_{\mathrm{i}}$ & Std Err & P-value & $\beta_{\mathrm{i}}$ & Std Err & P-value & $\beta_{\mathrm{i}}$ & Std Err & P-value \\
\hline Intercept & +881.50 & 45.75 & 0.03 & +0.34 & 0.04 & 0.07 & +1.00 & 0.00 & 0.00 \\
\hline M & -23.50 & 91.50 & 0.84 & -0.05 & 0.08 & 0.63 & +0.03 & 0.01 & 0.11 \\
\hline $\mathrm{CA}$ & -228.50 & 91.50 & 0.24 & -0.06 & 0.08 & 0.57 & +0.09 & 0.01 & 0.04 \\
\hline $\mathrm{P}$ & +6.50 & 91.50 & 0.95 & -0.04 & 0.08 & 0.72 & -0.05 & 0.01 & 0.08 \\
\hline $\mathbf{M} \times \mathbf{C A}$ & -149.00 & 91.50 & 0.35 & -0.04 & 0.08 & 0.69 & +0.04 & 0.01 & 0.09 \\
\hline $\mathrm{M} \times \mathbf{P}$ & -214.00 & 91.50 & 0.25 & -0.11 & 0.08 & 0.39 & -0.04 & 0.01 & 0.08 \\
\hline $\mathrm{CA} \times \mathrm{P}$ & +178.00 & 91.50 & 0.30 & +0.10 & 0.08 & 0.43 & +0.43 & 0.01 & 0.01 \\
\hline $\mathrm{R}^{2}$ & \multicolumn{3}{|c|}{0.95} & \multicolumn{3}{|c|}{0.84} & \multicolumn{3}{|c|}{1.00} \\
\hline
\end{tabular}

Where, material form $(\mathrm{M})$, chemical activation agents $(\mathrm{CA})$, and preparation methods $(\mathrm{P})$, and $\mathrm{R}^{2}$ : Goodness of fit.

Note: Numbers in bold print are statistically significant 

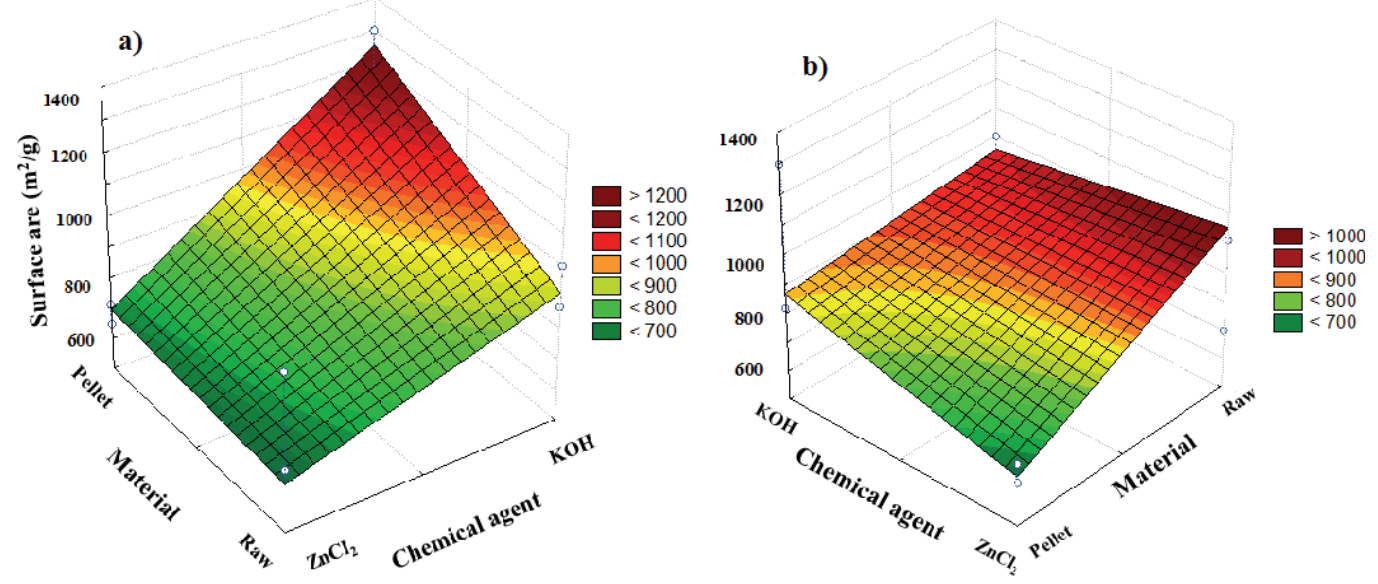

Fig. 1. Variation of surface area of prepared activated carbons at different chemical agents and material of rice straw a) Original condition and b) Carbonization condition.

Table 7 summarizes the EDX quantitative elemental analysis. Data show that the obtained products are essentially composed by carbon and oxygen, as is the case with ACs [47]. Other chemical elements with lower contents are also present (less than 1\%). Chlorine, the zinc and potassium elements originated from the activation agents $\left(\mathrm{ZnCl}_{2}\right.$ and $\left.\mathrm{KOH}\right)$. However, the other elements ( $\mathrm{Si}, \mathrm{S}, \mathrm{Ca} \mathrm{Cu}, \mathrm{Al}, \mathrm{Br})$ are naturally present on the rice straw, and are probably present in residual ashes, similar to the previously published results [31, 47, 48]. Since their preponderance is lower, we will consider that all ACs are structurally formed by only carbon and oxygen elements. It is obvious that hydrogen is also present but cannot be evidenced by spectroscopic X-ray elemental analysis such as EDX and XPS spectra.

Fig. 2 shows the large spectrum of X-ray photoelectron spectroscopy analysis. As we show, there are principally two lines that are centered at the binding energy of $286 \mathrm{eV}$ and $530 \mathrm{eV}$. These lines are respectively attributed to the emitted electron from carbon and oxygen [38, 49]. All the samples contain carbon as a major element, with the presence of oxygen in the surface, which agrees well the EDX results. To evidence the nature of constituents linked to carbon and oxygen atoms, we present in Fig. 3 (a-b) the $\mathrm{C} 1 \mathrm{~S}$ and O1S lines, respectively. Qualitatively, the
$\mathrm{C} 1$ s regions shows three components $(\mathrm{C} 1, \mathrm{C} 2$ and $\mathrm{C} 3)$, traducing the presence of carbon-carbon $(\mathrm{C}-\mathrm{C})$, carbonoxygen $(\mathrm{C}-\mathrm{O})$ and carbonyl groups $(\mathrm{C}=\mathrm{O})$ groupments $[49,50]$. The corresponding binding energies of these functionalities are respectively in the range 285.1, 287.4 and 289.1-289.6eV. Similarly, the O1s region also shows the presence of three features respectively ascribed to the $\mathrm{C}=\mathrm{O}(229,7-530,2 \mathrm{eV}), \mathrm{C}-\mathrm{O}(531.9-533.3 \mathrm{eV})$ and $\mathrm{C}-\mathrm{O}-\mathrm{C} / \mathrm{C}-\mathrm{OH}(534.3-536.0 \mathrm{eV})$ functionalities $[49,50]$. From this analysis, it seems that the resulting carbon structures contain the same elements as the case of other elaborated AC materials, but with different contents.

FTIR spectra of all prepared ACs are presented in Fig. 4. All the spectra are normalized by referring to the band situated at $1380 \mathrm{~cm}^{-1}$ ascribed to the $\mathrm{C}-\mathrm{C}$ sequences. Band positions and assignments are recorded according to the previously published results [51]. The shape of all the spectra is identical to those of other prepared ACs with different methods $[6,50$, 52]. The displayed features in the spectral domain ranging from $2900 \mathrm{~cm}^{-1}$ to $3300 \mathrm{~cm}^{-1}$ are attributed to the $\mathrm{OH}$ hydroxyl groups. However, those situated in the range $3500-3700 \mathrm{~cm}^{-1}$, are the signature of $\mathrm{OH}$ of carboxylic nature, showing that both acidic and basic entities are probably present in all samples. These results are in good agreement with chemical and textual

Table 6. Chemical and textual characteristics of commercial activated carbon cloth (CC).

\begin{tabular}{|c|c|c|c|c|c|c|c|c|c|}
\hline Carbon & $\begin{array}{c}\mathrm{S}_{\mathrm{N}_{2}}{ }^{\mathrm{a})} \\
\left(\mathrm{m}^{2} / \mathrm{g}\right)\end{array}$ & $\begin{array}{l}\mathrm{W}_{\mathrm{o}}\left(\mathrm{N}_{2}\right)^{\mathrm{b})} \\
\left(\mathrm{cm}^{3} / \mathrm{g}\right)\end{array}$ & $\begin{array}{c}\mathrm{W}_{\mathrm{o}}\left(\mathrm{CO}_{2}\right)^{\mathrm{c})} \\
\left(\mathrm{cm}^{3} / \mathrm{g}\right)\end{array}$ & $\begin{array}{c}\mathrm{L}_{\mathrm{o}}\left(\mathrm{N}_{2}\right)^{\mathrm{d})} \\
(\mathrm{nm})\end{array}$ & $\begin{array}{c}\mathrm{L}_{\mathrm{o}}\left(\mathrm{CO}_{2}\right)^{\mathrm{e})} \\
(\mathrm{nm})\end{array}$ & $\begin{array}{c}\text { Total acidic } \\
\text { groups }{ }^{f}(\mathrm{meq} / \mathrm{g})\end{array}$ & $\begin{array}{c}\text { Total basic } \\
\text { Groups }{ }^{\mathrm{g})}(\mathrm{meq} / \mathrm{g})\end{array}$ & $\mathrm{pH}_{\mathrm{pzc}}^{\mathrm{h})}$ & $\begin{array}{c}\text { Ashes }{ }^{\mathrm{j})} \\
(\%)\end{array}$ \\
\hline $\mathrm{CC}$ & 951 & 0.37 & 0.22 & 1.46 & 0.72 & 6.29 & 0.00 & 4.7 & 0.83 \\
\hline
\end{tabular}

a) Surface area determined from $\mathrm{N}_{2}$ adsorption isotherms at $77 \mathrm{~K}$,

b, c) Volumes of micropores determined by $\mathrm{N}_{2}$ and $\mathrm{CO}_{2}$ adsorption, respectively,

d, e) Mean widths of micropores determined with the Dubinin equation,

f) Concentration of acidic groups determined by titration with $\mathrm{NaOH}(0.1 \mathrm{~N})$,

g) Concentration of basic groups determined by titration with $\mathrm{HCl}(0.1 \mathrm{~N})$,

h) $\mathrm{pH}$ of the point of zero charge,

j) Ash content at $550{ }^{\circ} \mathrm{C}$. 
Table 7. Quantitative EDX elemental analysis for the selected ACs and CC.

\begin{tabular}{|c|c|c|c|c|c|c|c|c|c|c|c|}
\hline Carbon & $\% \mathrm{C}$ & $\% \mathrm{O}$ & $\% \mathrm{Cl}$ & $\% \mathrm{Si}$ & $\% \mathrm{~K}$ & $\% \mathrm{~S}$ & $\% \mathrm{Zn}$ & $\% \mathrm{Ca}$ & $\% \mathrm{Cu}$ & $\% \mathrm{Al}$ & $\% \mathrm{Br}$ \\
\hline 1 & 85.00 & 13.20 & 0.20 & 0.20 & 1.00 & 0.20 & 0.20 & --- & --- & -- & -- \\
\hline 2 & 80.78 & 9.78 & 0.34 & 0.18 & --- & 0.21 & 0.12 & 0.43 & 0.04 & 0.11 & --- \\
\hline 5 & 99.70 & --- & 0.20 & 0.72 & --- & --- & --- & --- & --- & -- & -- \\
\hline 7 & 98.58 & --- & 0.05 & 0.29 & --- & 0.05 & --- & 0.06 & 0.12 & -- & 0.08 \\
\hline 8 & 99.15 & --- & 0.06 & 0.05 & --- & ---- & 0.11 & --- & -- & -- & -- \\
\hline $\mathrm{CC}$ & 99.56 & --- & 0.18 & 0.10 & --- & --- & 0.16 & --- & --- & -- & -- \\
\hline
\end{tabular}

-- Means it's not detected

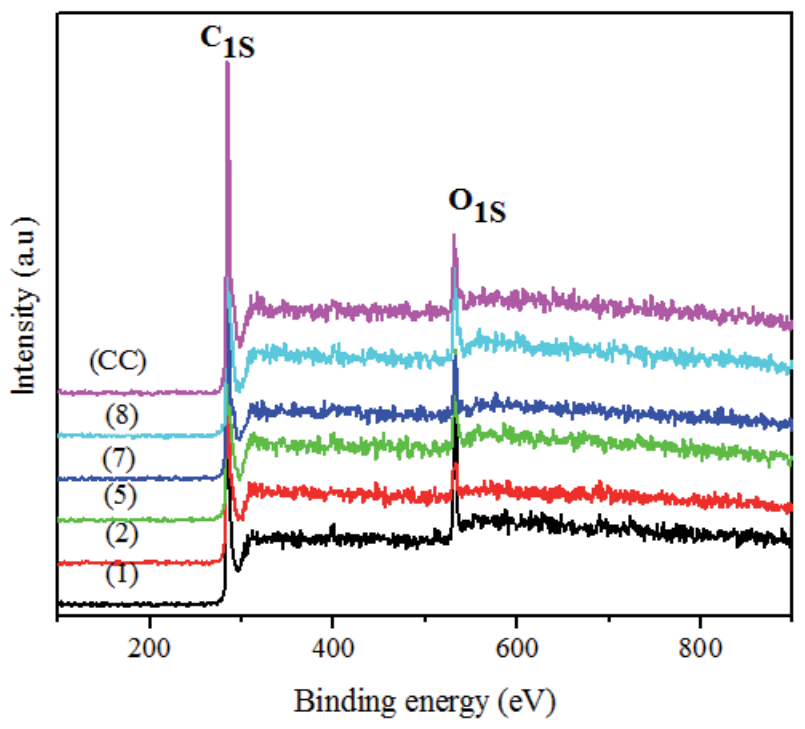

Fig. 2. XPS Large spectra of ACs (1), (2), (5), (7), (8), and CC.

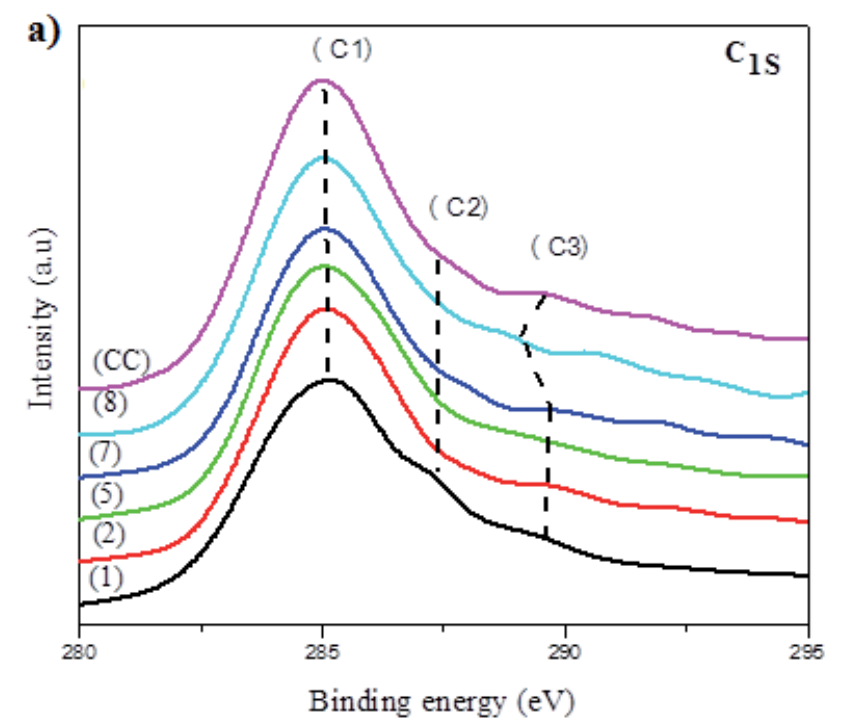

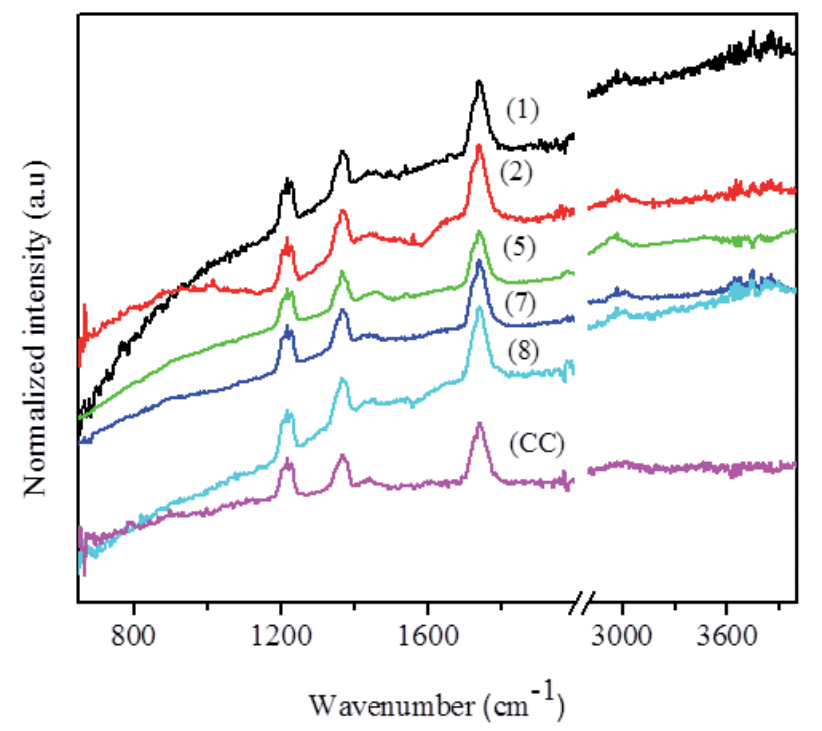

Fig. 4. FTIR spectra of ACs (1), (2), (5), (7), (8), and CC.

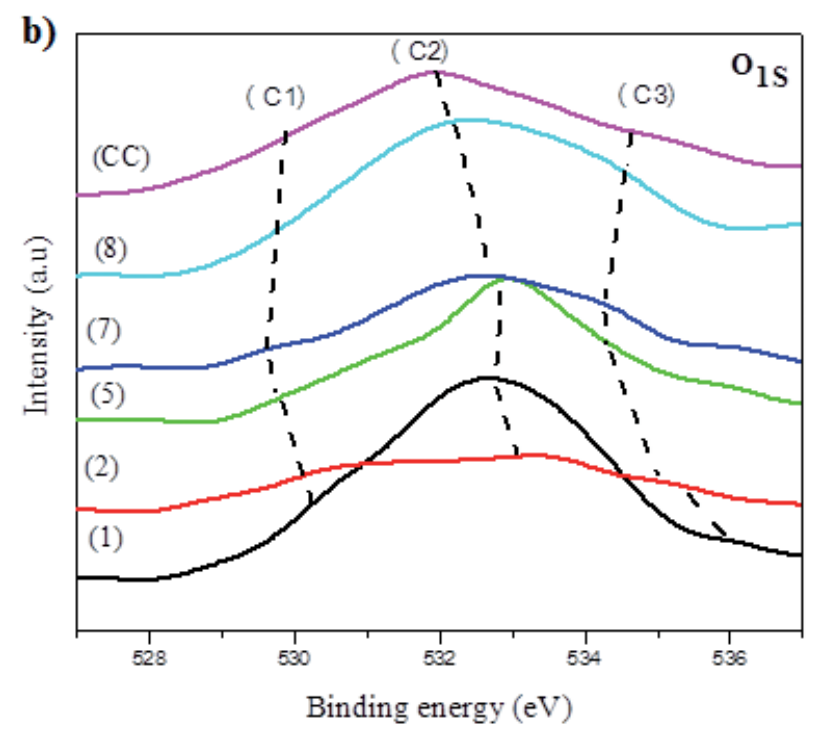

Fig. 3. a) C1S and b) O1s lines of for ACs (1), (2), (5), (7), (8), and CC. 

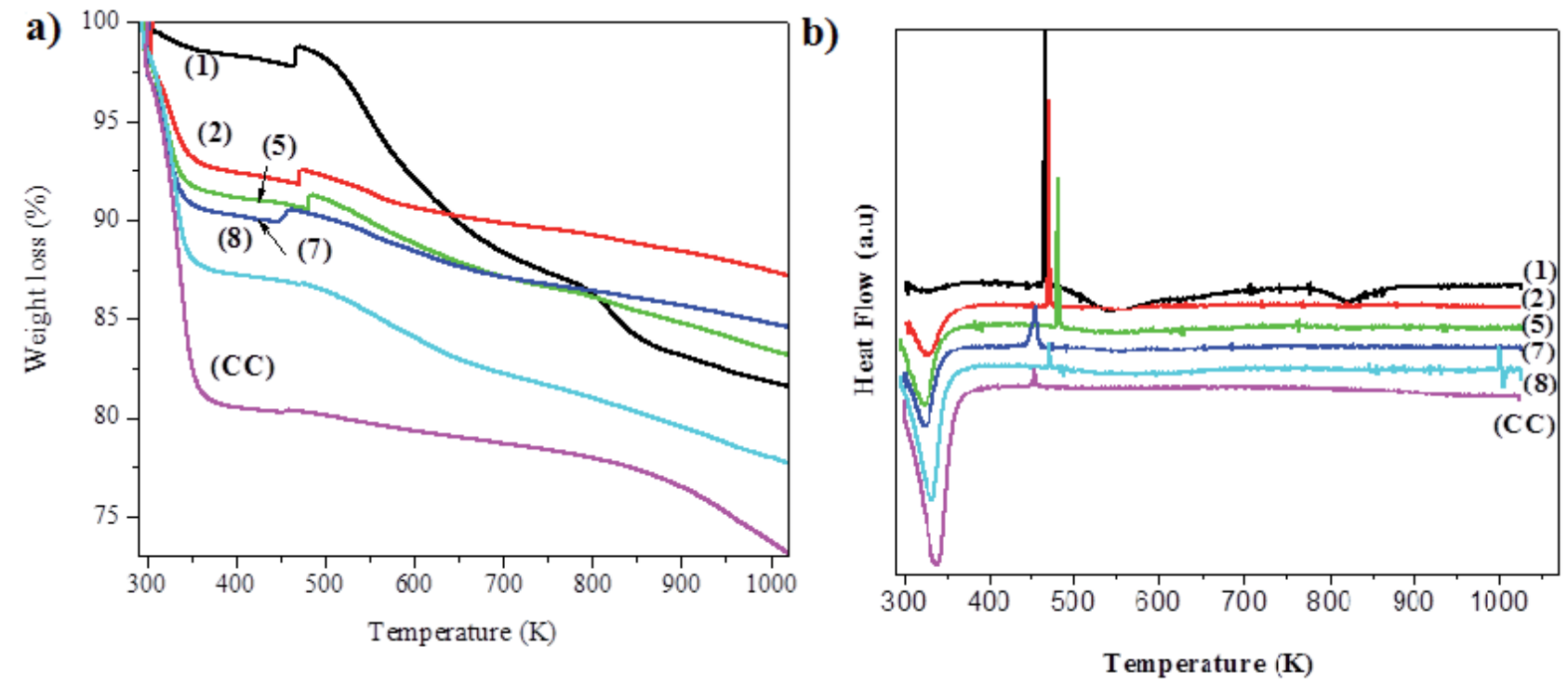

Fig. 5. a). TGA thermograms and b) DTA thermograms of ACs (1), (2), (5), (7), (8), and CC.

characteristics reported in Tables 4 and 6. Moreover, all the samples reveal the presence of three principal bands situated at $1210 \mathrm{~cm}^{-1}, 1380 \mathrm{~cm}^{-1}$, and $1730 \mathrm{~cm}^{-1}$. These three intense bands respectively denote the presence of $\mathrm{C}-\mathrm{O}, \mathrm{C}-\mathrm{C}$ and $\mathrm{C}=\mathrm{O}$ groups. It is also clearly seen that there is a weak band situated at $1450 \mathrm{~cm}^{-1}$ attributed to the $\mathrm{C}=\mathrm{C}$ groups. The particularity of samples 5 and 8 is that they exhibit an additional band in the range 1550-1600 attributed to the $\mathrm{C}=\mathrm{C}$ aliphatic sequences. Otherwise, samples (1) and (2) exhibit a relatively weak band situated at nearly $670 \mathrm{~cm}^{-1}$ that should be the consequence of $\mathrm{ZnCl}_{2}$ used as an activation agent.

The Oxygen and carbon contents can vary from one method to another. To evidence the preponderance of these elements and to make a difference between the used methods to prepare ACs, we present TGA analysis in Fig. 5a). As indicated by EDX and XPS results, carbon is the most preponderant element in all samples (more than $80 \%$ ), and $\mathrm{C}-\mathrm{C}$ bonding opening for ACs is the most thermally stable fragment. Typically their degradation occurs at higher temperature (more than $950^{\circ} \mathrm{K}$ ) [53,54]. For this reason, we present thermal analysis only on the temperature range corresponding to the loss of all other elements except carbon. As shown in Fig. 5a), the first decomposition stage in all samples occurs in the temperature lower than $373^{\circ} \mathrm{K}$. This first stage corresponds to the water and moisture and residual gazes presents on the samples. It is to note that this first region loss is more pronounced for the commercial sample, which is approximately $20 \%$.
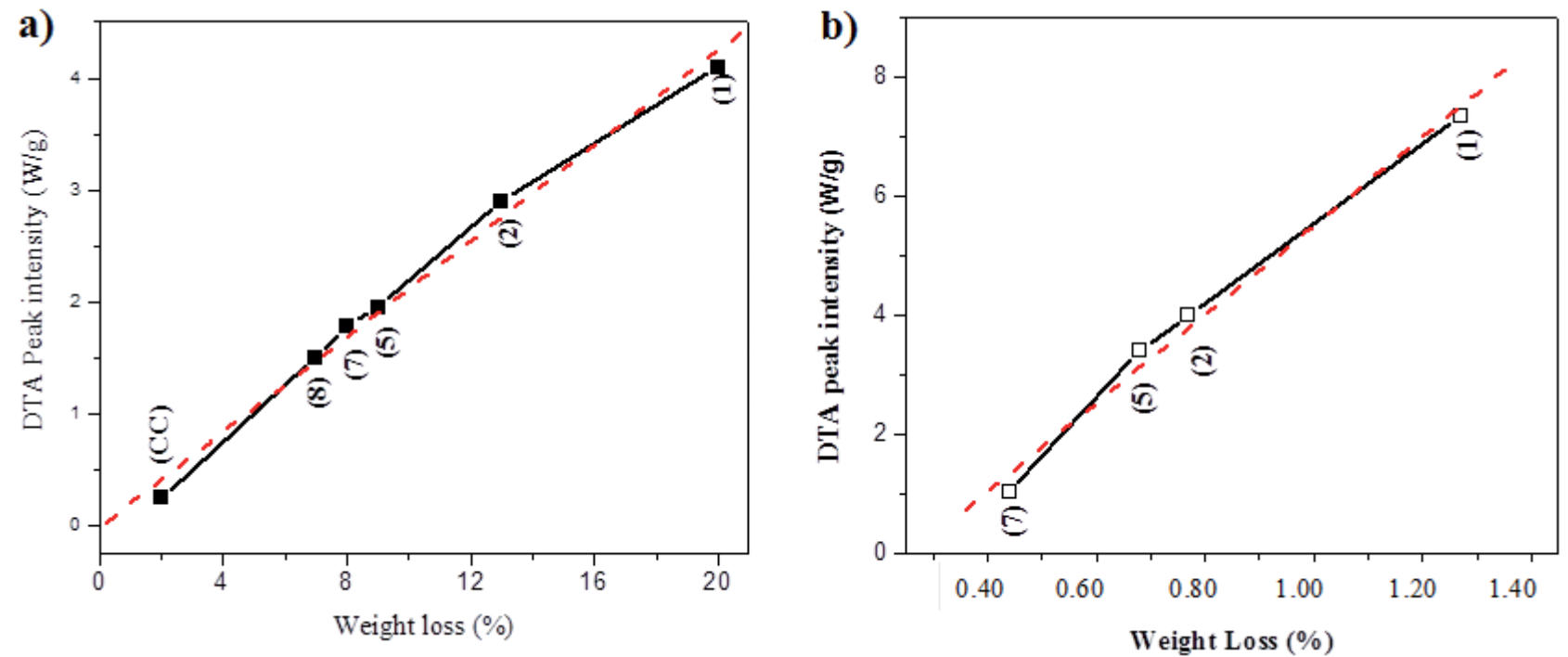

Fig. 6. Relationship Weight loss-DTA Peak intensity for ACs (1), (2), (5), (7), (8), and CC. a) in the temperature range T<373 K and b) in the temperature range $>455 \mathrm{~K}$. 

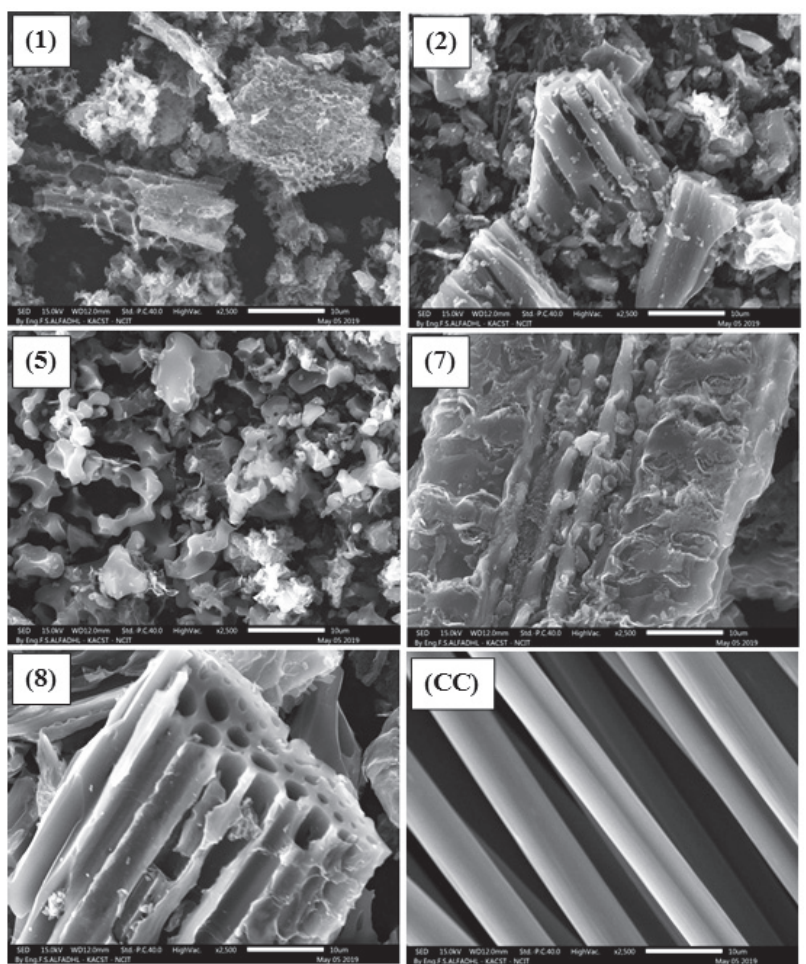

Fig. 7. SEM inspection for picture ACs (1), (2), (5), (7), (8), and CC.

However, in this temperature domain the weight loss corresponding to samples (1), (2), (5), (7), and (8) is evaluated at $2 \%, 7 \%, 8 \%, 9 \%$ and $13 \%$, respectively. This may be the consequence of microspore volumes for carbon graphitic structures, illustrating the preponderance of oxygenated elements. On the other hand, TGA thermo-grams illustrate the appearance of weight increase in a narrow temperature range of $455-465^{\circ} \mathrm{K}$, traducing an oxidation reaction. This behavior is not the case of samples (8) and (CC) due to the already access oxygen contents in the sample. It may be also due to the Archimedes effects, when the density of material is slightly decreased by increasing temperature. Except for sample (1), all others show a slight weight loss in the temperature range $470-900^{\circ} \mathrm{K}$, illustrating good thermal stability in this domain. This domain corresponds to the pure graphitic structure. In this thermal stage, sample (1) shows a monotonic weight decrease, illustrating a rapid decomposition process that could be due to the nature of aliphatic $\mathrm{C}$-C linking, such as organic oligomers/polymer or small molecules $[38,55]$. We think therefore that this product contains a mixture of aromatic and aliphatic sequences that can considerably affect miro-porous properties.

To better support the above-presented results, we present in Fig. 5b), DTA thermo-grams. In the first temperature range (lower than $373^{\circ} \mathrm{K}$ ) and by referring to TGA data, the corresponding weight loss is proportional to the intensity of the endothermic peaks. This relationship is presented at the onset of Fig. 6a), supporting the idea that the endothermic peak is the

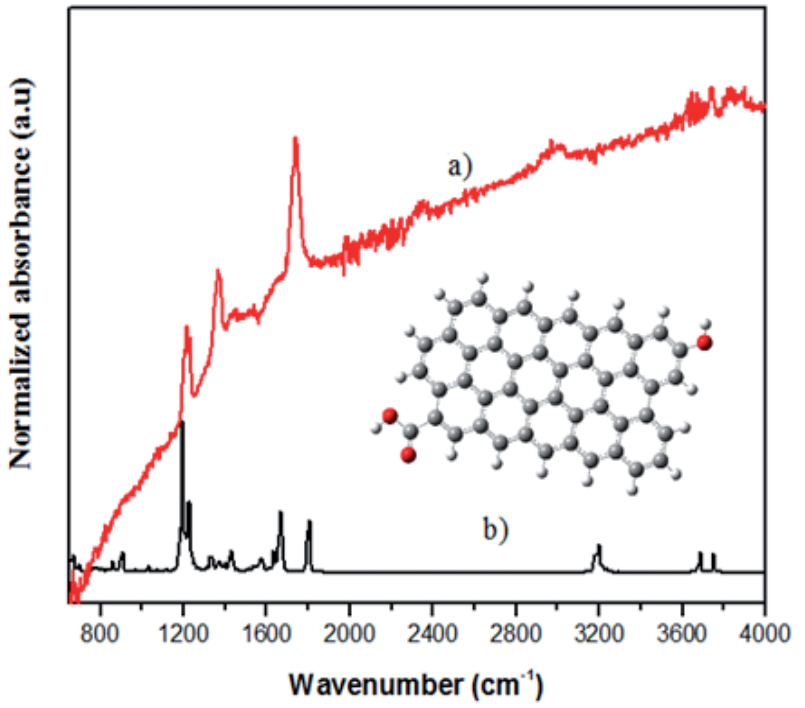

Fig. 8. Infrared spectra of ACs, a) Experimental b) theoretical based on the modeling structure.

consequence of water and moisture departure already indicated by TGA analysis. The already suggested oxidation reaction occurring in the temperature range $355-365^{\circ} \mathrm{K}$ is evidenced by an exothermic peak occurring on the same range. As illustrated by Fig. 6b), this exothermic peak also shows proportionality with the added weight loss due to the oxygen linking (onset of Fig. 6b)).

Fig. 7 shows the SEM pictures of prepared ACs. Except for samples (1) and (5), all others are characterized by highly porous and tubular structures. Both structures (1) and (5) are constituted by 3D interconnected spheres of carbon atoms with amorphous surface. The texture appears as a heterogeneous surface with a broad variety of randomly distributed macropores of different sizes. As discussed before in DTA and TGA analysis, the particularity of the sample (1) that appears in the form of irregular shaped aggregated particles lets us conclude that a mixture of aliphatic and graphitic structures is most probable. Samples (2), (7) and (8), however, are constituted by a porous structure having cracks and crevices with nearly regular tubular structures with the diameter varying from 2 to $3 \mathrm{~nm}$.

By correlating the experimental results, we can conclude that the molecular structure is composed by acidic and basic entities embedded on the graphic carbon structure. To support this hypothesis, DFT calculations are done on the proposed modelling structure. Fig. 8 shows both experimental and theoretical infrared spectra (the modelling structure is shown on the onset). The observed band intensities change and the slight shift of vibrational frequencies are due to the steric hindrance effects as illustrated in our previous calculations [56]. It may also be the consequence of differences in the intermolecular interactions due to the fact that calculations are done in gaseous phase and for isolated molecules. Therefore, good accordance in band 


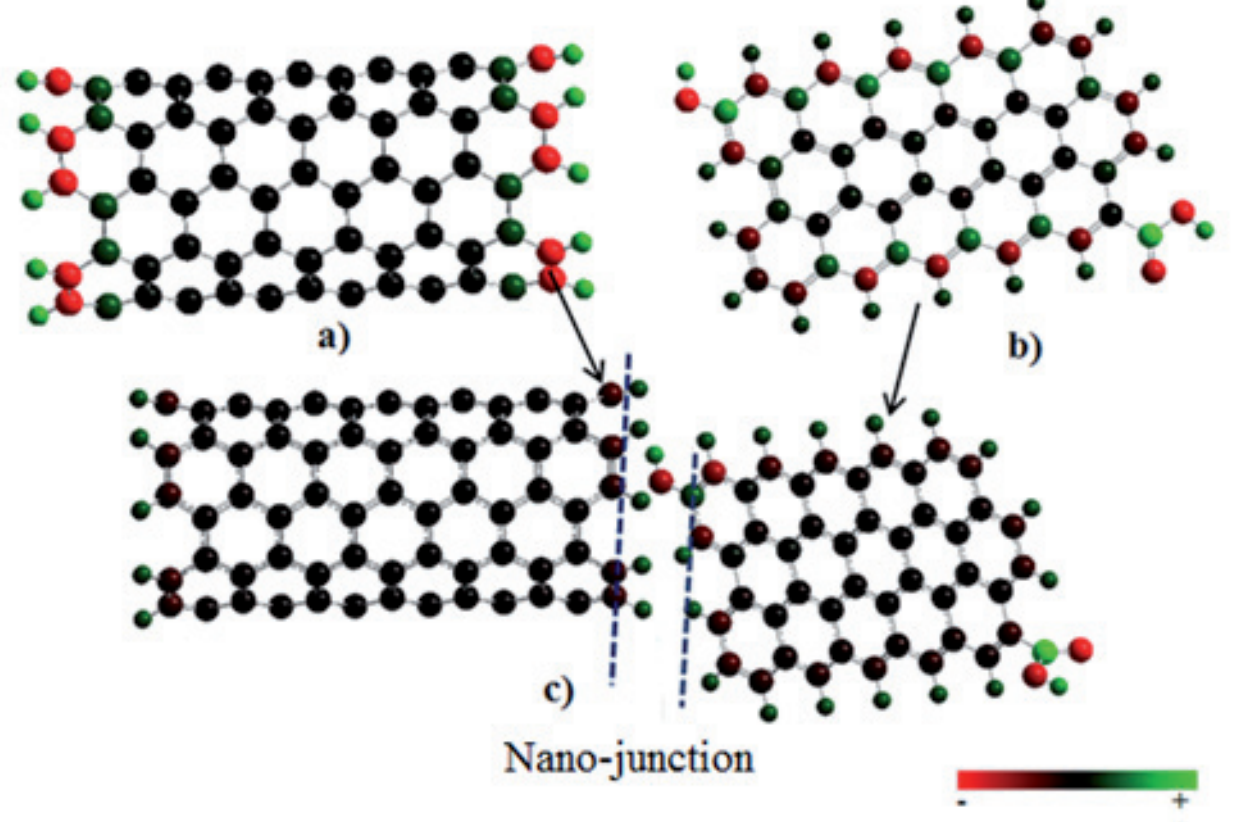

Fig. 9. Physical interaction between ACs \& SWCNTs and the change of atomic charge.

positions and intensities reflects a strong proof for the modeling structure justification. The final structure, however, is a mixture of graphitic carbon with the presence of both acidic and basic entities.

From the above-mentioned results, especially the higher porosity and higher surface area, it will be of interest to functionalize the obtained structure with single-walled carbon nanotubes (SWCNTs). Due to the compatibility with pore size, the SWCNT insertion can dramatically increase the characteristic surface area. The combination of both structures is optimized with the semi-empirical method using MP3 methods. The output structure is presented in Fig. 9, where results show a physical interaction in which hydroxyl $(\mathrm{O}-\mathrm{H})$ groupments are attracted by SWCNTS sidewall. This interaction is probably due to the higher Vander walls cohesive forces [57], and is followed by a modification of the charge distribution - especially for atoms near the hetero nano-junction for both compounds. The diminution of negative charges on the side wall indicates that there is a charge transfer from SWCNTs to ACs. These added charges compensate for the

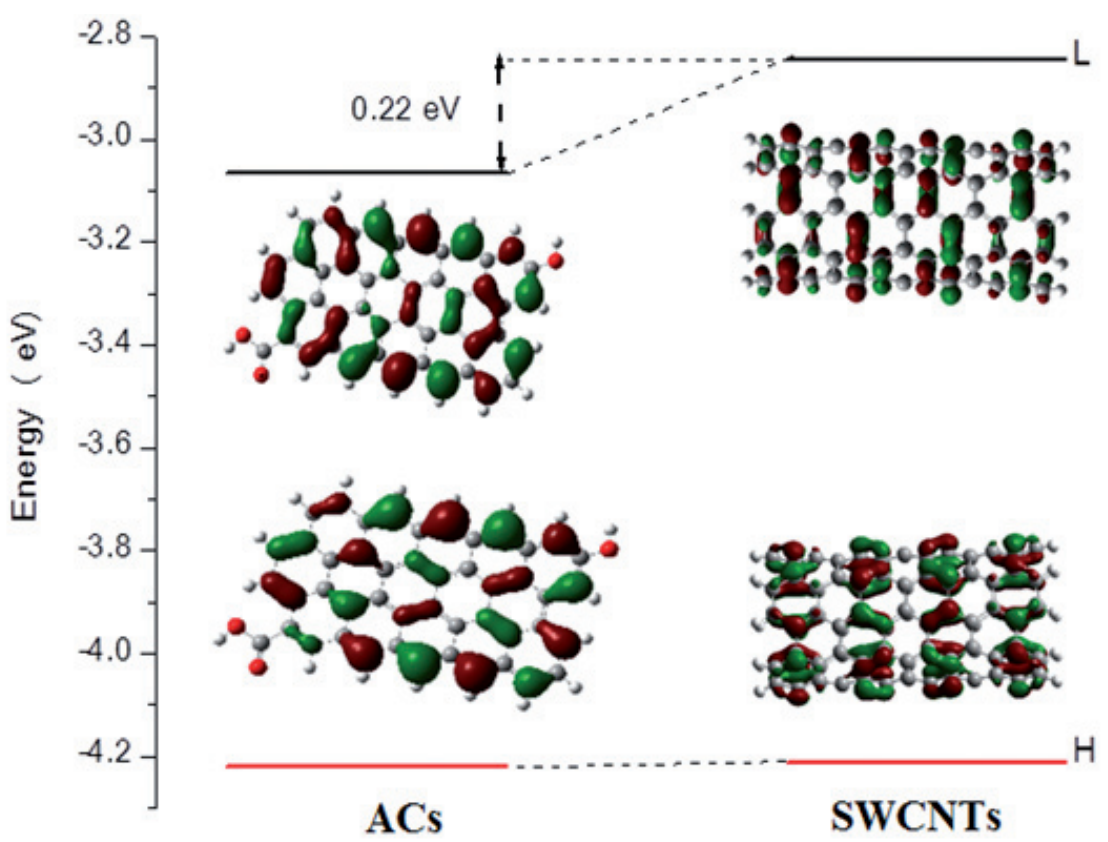

Fig. 10. Electronic structure of ACs and SWCNTs and their corresponding Frontier molecular orbitals. 
positive charges relative to $\mathrm{C}=\mathrm{C}$ carbon atoms situated at the side of the 2-dimentionnal ACs network.

In fact, the resulting interpenetrating network constituted well-dispersed bulk hetero-nano-junctions. Such small-diameter SWCNTs have previously proven to be significant for efficient bulk-heterojunction (BHJ) solar cells and or organic LEDs with other molecules $[58,59]$. Moreover, it is known that the use of a narrow range of SWCNTs chiralities leads to reducing the device design and control complexity. Moreover, the existence of carboxylic groups on the side of ACs can be further transformed by ester linkages [58]. The attachment of various molecules induces the electronic structure modification at the interface of SWCNTs [60]. The covalent functionalization causes a change in the hybridization of carbon from $\mathrm{sp} 2$ to $\mathrm{sp} 3$, and hence in the electronic structure. Excessive covalent functionalization completely destroys the electronic structure of SWNTs. In Fig. 10 we present the electronic structure and the corresponding molecular orbitals of both SWCNTs and ACs obtained by using DFT/6$31-G-d$ level. The used chirality $(5,5)$ as modeling structure for SWCNTs is adequate for the pore size distribution obtained from BET analysis. As presented, The HOMO-LUMO energies demonstrate that the $(5,5)$ SWCNTs exhibit a band gap of $1.16 \mathrm{eV}$. This value is nearly the same to that of silicon - the most used material for solar cell active layer [61]. Therefore, under illumination, a large absorption spectrum can be obtained covering UV, visible and near-infrared spectral range as suggested experimentally in some cases [61, 62]. Furthermore, the energetic difference at the nano-junction induces electron and hole separation, and certainly will contribute to decreasing the electron and hole radiative recombination. Based on the obtained energy values from the electronic structure, the SWCNTs represent the electron donor, and ACs will certainly be an electron-transporting layer as the case of SWCNTs/Fullerene nano-composites [61].

Molecular orbitals are of particular importance, namely those involving the most probable optical transition after energetic excitation sources. The highest occupied molecular orbital (HOMO) and the lowest unoccupied molecular orbital (LUMO) are directly related to the optical band gap, from which is derived the conductive nature of materials [63]. If the charge transfer is occurred, electrons will be conducted by the ACs LUMO molecular orbitals. However, holes might be transported by SWCNTS HOMO orbitals. From Fig. 10, it is also clearly seen that FMOs of LUMO energies are wrapped in the radial direction. However, those of HOMO are spread over the axial direction of SWCNTs. As the axial mobility is larger than the radial one, the configuration leads namely to a better conductive property [64]. Then the entire delocalization of either HOMO or LUMO orbitals on the entire molecular skeleton indicates that there is great spatial overlap between the HOMO and LUMO, and the transition from HOMO to LUMO may lead to strong optical adsorption of SWCNTS [65]. The above presented results are of great importance for photovoltaic application. Photo-excitations produced on the SWCNT skeleton would give rise to free electrons located in the unoccupied molecular orbital, helping to increase the short circuit current density and further enhance the conversion efficiency of the corresponding solar cell as previously reported for other donoracceptor compounds [66].

\section{Conclusions}

From BET, SEM and FTIR analysis, it is demonstrated that the use of $\mathrm{KOH}$ and raw rice straw were the main parameters that produce ACs with high surface area and porosity. The correlation of the structural results, including EDX, XPS, FTIR, DTA and TGA, with those obtained theoretically from DFT, lead us to conclude that the resulting product is constituted by a mixed carbon graphitic structure and both acidic/ basic entities. The prepared ACs have large pore sizes and their distribution exhibits good compatibility with lower radius SWCNTs. Their functionalization has been tested theoretically by the mean atomic charge modification, their electronic structure and their frontier molecular orbitals. The obtained results show that the resulting nano-materials exhibit charge transfer characteristics and can be used as an active layer in future photovoltaic applications.

\section{Acknowledgements}

The authors are grateful for the encouragement and support of Shaqra, Monastir, and Zagazig universities and King Abdulaziz City for Science and Technology.

\section{Conflict of Interest}

The authors declare no conflict of interest.

\section{References}

1. DAI Y., SUN Q., WANG W., LU L., LIU M., LI J., YANG S., SUN Y., ZHANG K., XU J., ZHENG W., HU Z., YANG Y., GAO Y., CHEN Y., ZHANG X., GAO F., ZHANG Y. Utilizations of agricultural waste as adsorbent for the removal of contaminants: A review. Chemosphere, 211, 235, 2018.

2. FAHIM I.S., CHBIB H., MAHMOUD H.M. The synthesis, production \& economic feasibility of manufacturing PLA from agricultural waste. Sustainable Chemistry and Pharmacy, 12, 100142, 2019.

3. ABDEL DAIEM M.M., SAID N., NEGM A.M. Potential energy from residual biomass of rice straw and sewage sludge in Egypt. In Procedia Manufacturing 22, 2018.

4. SAID N., EL-SHATOURY S.A., DÍAZ L.F., ZAMORANO M. Quantitative appraisal of biomass resources and their 
energy potential in Egypt. Renewable and Sustainable Energy Reviews, 24, 84, 2013.

5. Central agency for public mobilization and statistics (CAPMS), 2018 https://www.capmas.gov.eg/Pages/ IndicatorsPage.aspx?page_id $=6151 \&$ ind_id $=236$

6. BASTA A.H., LOTFY V.F., HASANIN M.S., TRENS P., EL-SAIED, H. Efficient treatment of rice byproducts for preparing high-performance activated carbons. Journal of Cleaner Production, 207, 284, 2019.

7. RUIZ B., FERRERA-LORENZO N., FUENTE E. Valorisation of lignocellulosic wastes from the candied chestnut industry. Sustainable activated carbons for environmental applications. Journal of Environmental Chemical Engineering, 5 (2), 1504, 2017.

8. LOTFY V.F., FATHY N.A., BASTA A.H. Novel approach for synthesizing different shapes of carbon nanotubes from rice straw residue. Journal of Environmental Chemical Engineering, 6 (5), 6263, 2018.

9. XUE M., LU W., CHEN C., TAN Y., LI B., ZHANG C. Optimized synthesis of banana peel derived porous carbon and its application in lithium sulfur batteries. Materials Research Bulletin, 112, 269, 2019.

10. ZHANG D., HE C., ZHAO J., WANG J., LI K. Facile synthesis of hierarchical mesopore-rich activated carbon with excellent capacitive performance. Journal of Colloid and Interface Science, 546, 101, 2019.

11. OGUNGBENRO A.E., QUANG D.V, AL-ALI K.A., VEGA L.F., ABU-ZAHRA M.R.M. Physical synthesis and characterization of activated carbon from date seeds for $\mathrm{CO}_{2}$ capture. Journal of Environmental Chemical Engineering, 6 (4), 4245, 2018.

12. OCAMPO-PÉREZ R., ABDEL DAIEM M.M., RIVERAUTRILLA J., MÉNDEZ-DÍAZ J.D., SÁNCHEZ-POLO M. Modeling adsorption rate of organic micropollutants present in landfill leachates onto granular activated carbon. Journal of Colloid and Interface Science, 385 (1), 2012.

13. ABDEL DAIEM M.M., RIVERA-UTRILLA J., SÁNCHEZ-POLO M., OCAMPO-PÉREZ R. Single, competitive, and dynamic adsorption on activated carbon of compounds used as plasticizers and herbicides. Science of the Total Environment, 537, 2015.

14. SÁNCHEZ-POLO M., ABDEL DAIEM M.M., OCAMPOPÉREZ R., RIVERA-UTRILLA J., MOTA A.J. Comparative study of the photodegradation of bisphenol A by $\mathrm{HO} \cdot \mathrm{SO}_{4} \cdot-$ and $\mathrm{CO}_{3} \cdot-/ \mathrm{HCO}_{3} \cdot$ radicals in aqueous phase. Science of the Total Environment, 463, 2013.

15. MÉNDEZ-DÍAZ J.D., ABDEL DAIEM M.M., RIVERAUTRILLA J., SÁNCHEZ-POLO M., BAUTISTATOLEDO I. Adsorption/bioadsorption of phthalic acid, an organic micropollutant present in landfill leachates, on activated carbons. Journal of Colloid and Interface Science, 369 (1), 2012.

16. RIVERA-UTRILLA J., SÁNCHEZ-POLO M., ABDEL DAIEM M. M., OCAMPO-PÉREZ R. Role of activated carbon in the photocatalytic degradation of 2,4-dichlorophenoxyacetic acid by the UV/TiO $/$ activated carbon system. Applied Catalysis B: Environmental, 126, 2012.

17. OCAMPO-PEREZ R., RIVERA-UTRILLA J., ABDEL DAIEM M.M., SÁNCHEZ-POLO M. Integrated technologies based on the use of activated carbon and radiation to remove contaminants present in landfill leachates. Landfills and Recycling Centers: Processing Systems, Impact on the Environment and Adverse Health Effects. 2015.
18. ABDEL DAIEM M.M., SÁNCHEZ-POLO M., RASHED A.S., KAMAL N., SAID N. Adsorption mechanism and modelling of hydrocarbon contaminants onto rice straw activated carbons, Polish Journal of Chemical Technology, 21 (4), 1, 2019.

19. AHMEDNA M., MARSHALL W.E., RAO R.M. Production of granular activated carbons from select agricultural by-products and evaluation of their physical, chemical and adsorption properties1Louisiana Agricultural Experiment Station manuscript 99-21-0066.1. Bioresource Technology, 71 (2), 113, 2000.

20. DAIFULLAH A.A.M., YAKOUT S.M., ELREEFY S.A. Adsorption of fluoride in aqueous solutions using $\mathrm{KMnO}_{4}$ modified activated carbon derived from steam pyrolysis of rice straw. Journal of Hazardous Materials, 147 (1), 633, 2007.

21. ELMOUWAHIDI A., ZAPATA-BENABITHE Z., CARRASCO-MARÍN F., MORENO-CASTILLA C. Activated carbons from $\mathrm{KOH}$-activation of argan (Argania spinosa) seed shells as supercapacitor electrodes. Bioresource technology, 111, 185, 2012.

22. ZHU H., WEI J., WANG K., WU D. Applications of carbon materials in photovoltaic solar cells. Solar Energy Materials and Solar Cells, 93 (9), 1461, 2009.

23. DASARI K.K., GUMTAPURE V. Activated carbonbased dye-sensitized solar cell for development of highly sensitive temperature and current sensor. Materials Research Express, 6 (8), 85531, 2019.

24. UNE-EN 14774-2, Solide biofuels, Determination of moisture content, simplified method. 2010.

25. UNE-EN 14775, Solide biofuels, Determination of ash content. 2010

26. UNE-EN 15148, Solide biofuels, Determination of the content of volatile matter. 2010

27. UNE-EN 15104, Solide biofuels, Determination of total content of carbon, hydrogen, and nitrogen, Instrumental methods. 2011.

28. UNE-EN 15290, Solide biofuels, Determination of major elements. 2011

29. SLUITER A., HAMES B., RUIZ R., SCARLATA C., SLUITER J., TEMPLETON D., CROCKER D. Determination of structural carbohydrates and lignin in biomass. Laboratory analytical procedure, 1617, 1, 2008.

30. SOMOGYI M. A new reagent for the determination of sugars. Journal of Biological Chemistry, 160, 61, 1945.

31. SAID N., ABDEL DAIEM M.M., GARCÍA-MARAVER A., ZAMORANO M. Influence of densification parameters on quality properties of rice straw pellets. Fuel Processing Technology, 138, 2015.

32. UNE-EN 16127, Solide biofuels, Determination of length and diameter of pellets. 2012

33. UNE-EN 15150, Solide biofuels, Determination of particle density; 2012.

34. UNE-EN 15103, Solide biofuels, Determination of bulk density. 2010.

35. UNE-EN 15210, Solide biofuels, Determination of mechanical durability of pellet and briquettes: pellets part $1,2010$.

36. RIVERA-UTRILLA J., SÁNCHEZ-POLO M. Ozonation of naphthalenesulphonic acid in the aqueous phase in the presence of basic activated carbons. Langmuir, 20 (21), 9217, 2004.

37. RIVERA-UTRILLA J., BAUTISTA-TOLEDO I., FERROGARCIA M.A., MORENO-CASTILLA C. Bioadsorption of $\mathrm{Pb}$ (II), $\mathrm{Cd}$ (II), and $\mathrm{Cr}$ (VI) on activated carbon from aqueous solutions. Carbon, 41 (2), 323, 2003. 
38. ZAIDI B., AYACHI S., MABROUK A., MOLINIE P., ALIMI K. Changes of the properties of poly-phenylenevinylene-ether and C1-4 poly-phenylene-vinylene-ether with iodine pressure and annealing. Polymer degradation and stability, 79 (1), 183, 2003.

39. MBAREK M., ZAIDI B., WÉRY J., ALIMI K. Structureproperties correlation of copolymers derived from poly (phenylene vinylene)(PPV). Synthetic Metals, 162 (19-20), 1762, 2012.

40. KHALIFA I. BEN, BARGAOUI S., SAID A.H., AYACHI S., ZAIDI B., WÉRY J., ALIMI K. About some properties of electro-synthesized short Oligo (Para-Fluoro-Anisole) (OPFA): A combined experimental and theoretical study. Journal of Molecular Structure, 997 (13), 37, 2011.

41. BECKE A.D. Density-functional thermochemistry. III. The role of exact exchange. The Journal of Chemical Physics, 98 (7), 5648, 1993.

42. LEE C., YANG W., PARR R.G. Development of the ColleSalvetti correlation-energy formula into a functional of the electron density. Physical review B, 37 (2), 785, 1988.

43. MBAREK M., ZAIDI B., ALIMI K. Theoretical study of the alkoxyls groups effect on PPV-ether excited states, a relationship with femtosecond decay. Spectrochimica Acta Part A: Molecular and Biomolecular Spectroscopy, 88, 23, 2012.

44. GIRI P.K., BHATTACHARYYA S., SINGH D.K., KESAVAMOORTHY R., PANIGRAHI B.K., NAIR K.G.M. Correlation between microstructure and optical properties of $\mathrm{ZnO}$ nanoparticles synthesized by ball milling. Journal of Applied Physics, 102 (9), 93515, 2007.

45. RASHIDI N.A., YUSUP S., BORHAN A. Isotherm and thermodynamic analysis of carbon dioxide on activated carbon. Procedia engineering, 148, 630, 2016.

46. GUO F., JIANG X., JIA X., LIANG S., QIAN L., RAO Z. Synthesis of biomass carbon electrode materials by bimetallic activation for the application in supercapacitors. Journal of Electroanalytical Chemistry, 844, 105, 2019.

47. SATAYEVA A.R., HOWELL C.A., KOROBEINYK A.V, JANDOSOV J., INGLEZAKIS V.J., MANSUROV Z.A., MIKHALOVSKY S.V. Investigation of rice husk derived activated carbon for removal of nitrate contamination from water. Science of the Total Environment, 630, 1237, 2018.

48. SAID N., ABDEL DAIEM M.M., GARCÍA-MARAVER A., ZAMORANO M. Reduction of ash sintering precursor components in rice straw by water washing. BioResources, 9 (4), 2014.

49. LIU F., LIU Q., LIU Y., XUE R.T., LI P., FAN X.M. Synthesis and photocatalytic activity of cubic cuprous oxide supported on activated carbon fibers. Chemical Physics Letters, 718, 54, 2019.

50. ELAIYAPPILLAI E., SRINIVASAN R., JOHNBOSCO Y., DEVAKUMAR P., MURUGESAN K., KESAVAN K., JOHNSON P.M. Low cost activated carbon derived from Cucumis melo fruit peel for electrochemical supercapacitor application. Applied Surface Science, 486, 527, 2019.

51. LIN-VIEN D., COLTHUP N.B., FATELEY W.G., GRASSELLI J.G. The handbook of infrared and Raman characteristic frequencies of organic molecules. Elsevier. 1991.
52. AHMED M.B., JOHIR M.A.H., ZHOU J.L., NGO H.H., NGHIEM L.D., RICHARDSON C., BRYANT M.R. Activated carbon preparation from biomass feedstock: Clean production and carbon dioxide adsorption. Journal of Cleaner Production, 225, 405, 2019.

53. BAZAN A., NOWICKI P., PÓŁROLNICZAK P., PIETRZAK R. Thermal analysis of activated carbon obtained from residue after supercritical extraction of hops. Journal of Thermal Analysis and Calorimetry, 125 (3), 1199, 2016.

54. DEVRIM Y., ALBOSTAN A. Graphene-supported platinum catalyst-based membrane electrode assembly for PEM fuel cell. Journal of Electronic Materials, 45 (8), 3900, 2016.

55. ZAIDI B., AYACHI S., MABROUK A., FAVE J.-L., MOLINIE P., GHEDIRA M., ALIMI K. Thin films of insoluble copolymer derived from poly (phenylenevinylene) obtained by thermal evaporation under vacuum. Journal of applied polymer science, 89 (11), 3091, 2003.

56. ZAIDI B., BOUZAYEN N., WÉRY J., ALIMI K. Grafting of oligo-N-vinyl carbazole on single walled carbon nanotubes. Journal of Molecular Structure, 971 (1-3), 71, 2010.

57. ZHANG L.C. On the mechanics of single-walled carbon nanotubes. Journal of Materials Processing Technology, 209 (9), 4223, 2009.

58. RAO C.N.R., VOGGU R. Charge-transfer with graphene and nanotubes. Materials today, 13 (9), 34, 2010.

59. BOUAZIZI H., MABROUK A., BRAIEK M.B., MESTIRI T., ALIMI K. New conjugated organic matrixcarbon nanotube functionalization: DFT modeling and spectroscopic analysis. Journal of Physics and Chemistry of Solids, 136, 109131, 2020.

60. TASIS D., TAGMATARCHIS N., BIANCO A., PRATO M. Chemistry of carbon nanotubes. Chemical reviews, 106 (3), 1105, 2006.

61. GONG M., SHASTRY T.A., XIE Y., BERNARDI M., JASION D., LUCK K.A., HERSAM M.C. Polychiral semiconducting carbon nanotube-fullerene solar cells. Nano letters, 14 (9), 5308, 2014.

62. PFOHL M., TUNE D.D., GRAF A., ZAUMSEIL J., KRUPKE R., FLAVEL B.S. Fitting single-walled carbon nanotube optical spectra. ACS omega, 2 (3), 1163, 2017.

63. BOUZAYEN N., SADKI H., MBAREK M., BOUACHRINE M., BENNANI M.N., WÉRY J., ALIMI K. Synthesis, characterization, DFT and TD-DFT studies of novel carbazole-based copolymer used in high efficient dye-sensitized solar cells. Polymer Testing, 66, 78, 2018.

64. STALLARD J.C., TAN W., SMAIL F.R., GSPANN T.S., BOIES A.M., FLECK N.A. The mechanical and electrical properties of direct-spun carbon nanotube mats. Extreme Mechanics Letters, 21, 65, 2018.

65. LV X., LI Z., LI S., LUAN G., LIANG D., TANG S., JIN R. Design of acceptors with suitable frontier molecular orbitals to match donors via substitutions on perylene diimide for organic solar cells. International journal of molecular sciences, 17 (5), 721, 2016.

66. GUO X., BAUMGARTEN M., MÜLLEN K. Designing $\pi$-conjugated polymers for organic electronics. Progress in Polymer Science, 38 (12), 1832, 2013. 